\title{
The Transition in Dutch water management
}

\author{
Published in Regional Environmental Change, vol.5, p.164-176, 2005 \\ Rutger van der Brugge, Jan Rotmans, Derk Loorbach
}

\begin{abstract}
Over the past decades the Dutch people have been confronted with severe waterrelated problems, which are the result of an unsustainable water system, arising from human interventions in the physical infrastructure of the water system and the water management style. The claims of housing, industry, infrastructure and agriculture have resulted in increasing pressure on the water system. The continuous subsidence of soil and climate change has put pressure on the land. Hence, the nature and magnitude of water-related problems have changed. Longitudinal research of relevant national policy documents reveals that the water management regime has changed its water management style over the past thirty years from a technocratic scientific style towards an integral and participatory style. We have investigated if the historical development in Dutch Water management can be characterized as a transition. Based on longitudinal research through an integrated systems analysis, document research and expert interviews, we have reconstructed the historical narrative by using the transition concepts of multi-level and multi-phase. This research indicates that the shift in Dutch Water management can be characterized as a transition. This transition is currently in the take-off stage and near the acceleration stage. This is a crucial stage as long as the considerable differences between the strategic macro-vision and the practical implementation at the micro-level remains. As long as these levels are not compatible (modulation), the transition will not be completed successfully. Transition management as multi-level governance model should therefore be adopted to facilitate the modulation.
\end{abstract}

Keywords: Water management, Transitions, Transition management, sustainability 


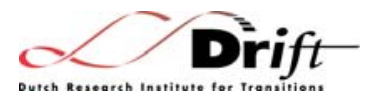

\section{INTRODUCTION}

Dutch water management has been recognized worldwide for its capabilities to control coastal and inland waters in order to guarantee safety and maintaining reliable water functions for agriculture, shipping and industry. Being a river-delta and having more than $50 \%$ of land beneath sea-level, the Dutch have a century-long tradition of fighting the water and trying to control it. In this way much of the water system is canalised and the surrounding area protected by dams and dikes. This technocratic-scientific regime has been dominant well into the $20^{\text {th }}$ century (Bosch \& Van der Ham, 1998; Van der Ham, 1999; Lintsen, 2002). It resulted in a highly sophisticated and widely branched, but relatively closed water defence system.

In 1993 and 1995, the Netherlands experienced two major floods of the rivers Meuse and Rhine, followed by high levels of regional waters in 1998. The sudden waterrelated problems led parliament to question current water management practices. Indeed, the installed committee-Tielrooy stated in their report Water management for $21^{\text {st }}$ century' that 'Dutch water management is not sufficiently prepared to meet the challenges of climate change effects in the next century' (CW21, 2000). In the three years after, the river Meuse almost flooded two times (in 2001 \& 2002) and in 2003 without any warning signal from the regional water board a small regional dike in Wilnis broke due to prolonged periods of drought.

These water-related problems in the Netherlands are symptoms of a deeper lying, fundamental problem, arising from the whole of human interventions in the natural water system over the last centuries. On the one hand the increasing spatial claims from agriculture, industry, traffic, housing and infrastructure as a result of growing economic development, increased population density and changing life-styles, led to a growing pressure on the water system. On the other hand the continuous subsidence of soil, the rising sea level and the decreasing capacity to retain water due to loss of nature have resulted in pressure from water on land. In this changing landscape, the water engineers were predominantly occupied with meeting the increasing societal demands by the fast drainage of redundant water, canalising rivers and the construction of dams and dikes. Now it becomes increasingly clear that this 'pumping-drainage-dike raising' strategy has not resulted in a sustainable water system as many calamities have occurred. The incremental reduction of space for the natural water system (polders and usage of river forelands) and changes in the water system itself such (reduction of the natural riverbed and hydrological conditions) has manifested itself in social damage (reduced safety), financial damage (floods, droughts, dike breaks) and ecological damage (drought, loss of water quality). In the near future the damage is expected to increase substantially and could be regarded as unsustainability symptoms of the current water system in the Netherlands.

The complex water problem is a so-called 'persistent' problem. Persistent problems are new types of societal problems that are characterized by significant complexity, structural uncertainty, high stakes for a diversity of stakeholders involved, and governance problems (Dirven, Rotmans and Verkaik, 2002). This feeds back to what Rittel and Webber (1973) describe as 'wicked problems': ill-structured problems in 


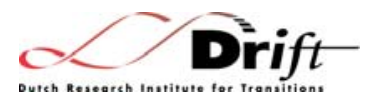

which complex societal interactions, highly uncertain physical processes and management dilemmas are present. We consider persistent problems as being of an even higher degree of complexity than wicked problems, because they are deeply rooted in our societal structures and institutions (Rotmans, 2003). The water problem is persistent because water has multiple manifestations, multiple functions and multiple values; as a result of this many stakeholders are involved with different interests and high stakes, making it complex and hard to manage. There is no such thing as the single water problem, because the different forms of water (rainwater, groundwater, surface water, sea water) manifest themselves in different issues: water demand and water supply, water scarcity, waste water treatment, sea level rise, and the alteration of the hydrological cycle. Water has also different functions in our society: an economic function for navigation and agriculture, an ecological function for sustaining ecosystems, and a social function in terms of safety and drinking water supply. Along the same line of reasoning, water also represents different values: an economic value expressed as the utility value of water by using some kind of pricing mechanism, an ecological value expressed as the water regulation services for ecosystems, and a social value, indicating the cultural and emotional meaning of water. Because water differs in time, place and manifestation only an integrated approach addressing the multiplicity of water makes sense. This, however, requires a different form of water management than the traditional one, managing for multiple cases at different scale levels: flood control, drought, municipal supply, hydroelectricity, irrigation, recreation and ecological preservation. Water managers can no longer optimise one particular utility function, but have to manage across multiple utilities and multiple stakeholders. Furthermore, water management is constrained by physical characteristics, regulation, contracts and politics. Thus, integral water management needs to be pluralistic, involving multiple stakeholders who represent multiple perspectives (set of values, biases and preferences).

The changing nature and scope of the water problem and the accumulating waterrelated damage and costs force us to manage the water in a more innovative and sustainable manner. In the Netherlands this change in water management already started decades ago, as shown by a comparison of the subsequent National Policy Memoranda on Water Management (Rijkswaterstaat, 1964, 1982, 1989, 1998). This longitudinal research shows that there has been a fundamental shift over the past thirty years from technocratic water engineering to integral and participatory water management. Whereas integral water management perceives the (context-specific) water system as a whole, integrating social, ecological and physical components of the water system, technocratic water management focuses on the physical processes within the water system. These days water is postulated as a guiding principle in spatial planning, meaning that water is one of the dominating issues in spatial planning processes. The ecological functions and values of water have become more important at the cost of the agricultural function and economic value of water (Kamphuis, personal communication). This is illustrated by emerging metaphors and mantras in the Dutch water arena such as "Room for water", "From Stemming to Accommodating water" and "Water as a friend rather than an enemy", indicating the significant changes in current water management. 
We have investigated if this shift in Dutch Water management can be characterized as a transition. In order to analyse the origin, dynamics and chances and barriers of this water transition, we did a longitudinal research of Dutch water management over the past three decades. We have reconstructed the historical narrative by using the transition concepts of multi-level and multi-phase based on extensive literature survey as well as a series of in-depth interviews with Dutch water experts who played important roles in this transformation process. Before we present this analysis, the concepts of transitions and transition management will be explained. We conclude with the implications of transition management for implementing integral water management strategies.

\section{TRANSITIONS}

A transition is a structural change in the way a societal system operates. A transition is a long-term process (25-50 years) resulting from a co-evolution of cultural, institutional, economical, ecological and technological processes and developments on various scale levels (Rotmans et al., 2000). An often quoted example of a more or less 'managed' transition is the transition from a coal based energy supply system to a gas/oil based energy supply system that happened in the Netherlands during the 1950's and 1960's (Verbong, 2000). During a transition different developments and events on different scale levels from different domains positively reinforce each other (Rotmans et.al. 2000). A transition can therefore be described as a process of the coevolution of markets, networks, institutions, technologies, policies, individual behaviour and autonomous trends from one relatively stable system state to another. This can be illustrated by an S-shaped curve (Figure $1 \& 2$ ). Although this is a highly simplified curve, it shows that a transition pathway could be considered as a system transformation away from slow equilibrium dynamics through a period of quick and instable development reverting to relative stability again (Rotmans, 1994). In between the two equilibrium states there is a period of rapid change in which the system undergoes irreversible change and (re-) organises itself again.

A pre-requisite for transitions to happen, is that several developments in different domains (ecological, socio-cultural, economic, institutional, technological) interact in such a way that they positively reinforce each other. Transitions are the result of slow social change and short-term fluctuations or events that suddenly initiate a highly non- linear response. Figure 1 illustrates a transition as complex set of cogwheels that engage and interact with one another. It could easily lead to an interlock, but once in a while they reinforce each other and start turning into one and the same direction. 


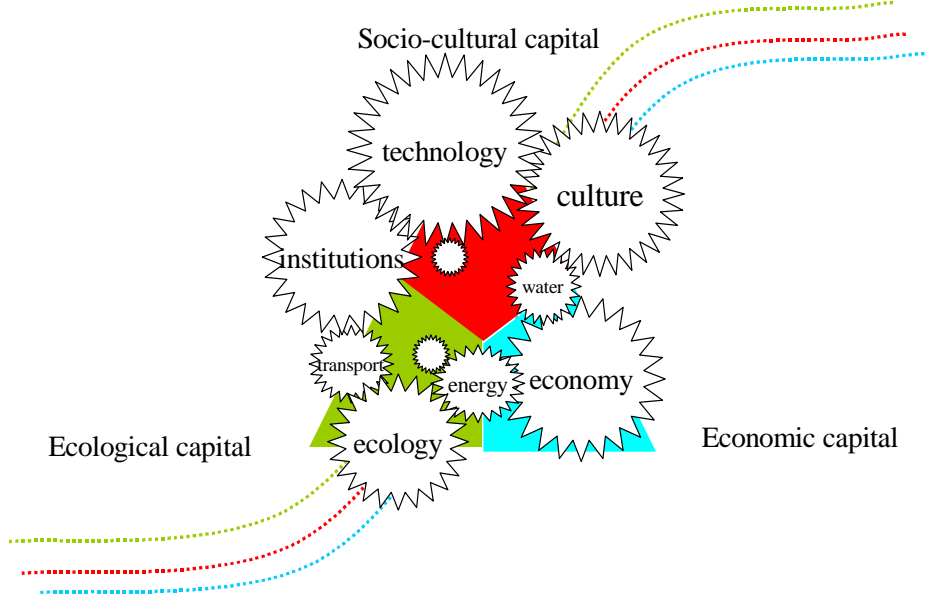

Figure 1. Metaphorical illustration of a transition as a complex set of societal cogwheels (Martens \& Rotmans, 2002.) In the predevelopment phase of the transition the cogwheels interlock. In the take-off and acceleration phase, the wheels start turning and reinforce each other (the slope of the curve(s) increases). In the stabilization phase the cogwheels interlock again, however, the new equilibrium is fundamentally different from the initial one.

There are three key concepts that form the basis of transition theory: multi-stage, multi-level and transition management. The multi-stage concept approaches transitions from the viewpoint of the speed of change. From this starting point a transition than can be described in four stages or phases (Rotmans et al. 2000), (Figure 2).

(i) a pre-development phase of dynamic equilibrium where the status quo does not visibly change but changes take place under the surface;

(ii) a take-off phase in which thresholds are reached and the state of the system begins to shift;

(iii) an acceleration phase where visible structural changes take place rapidly through an accumulation of socio-cultural, economic, ecological and institutional changes that reinforce each other;

(iv) a stabilization phase where the speed of social change decreases and a new dynamic equilibrium is reached. 


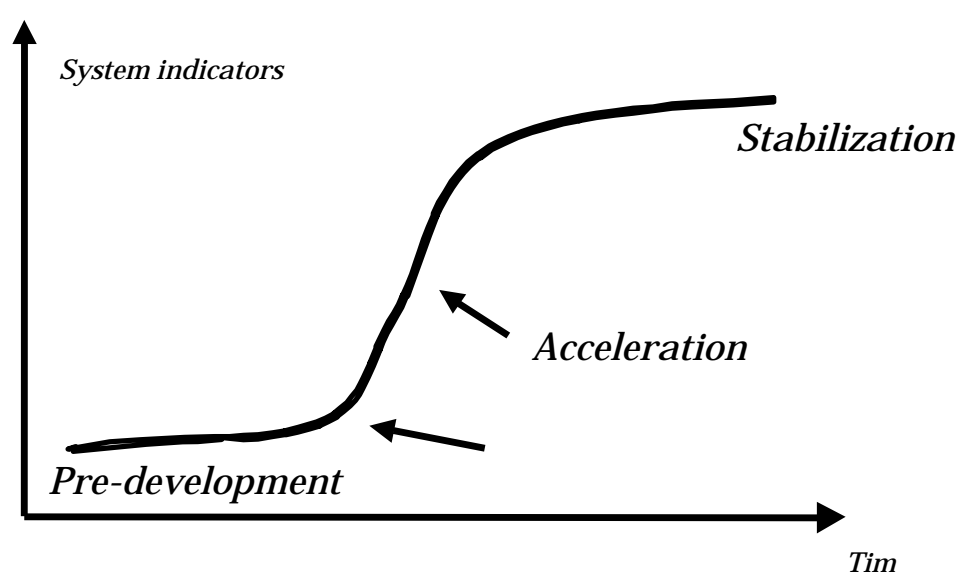

Figure 2. A transition is the shift between two dynamic equilibria that can be described by a set of system indicators. In the transition process, four phases can be distinguished. In the predevelopment these indicators change only marginally. In the take-off and acceleration phase the indicators change

with increasing speed. In the stabilization a new equilibrium is reached (Rotmans et al., 2002).

Note that the speed of change in transition processes is a relative notion, which necessitates the definition of system borders.

The second transition concept is the multi-level concept, which marks the division between functional scale levels at which transition processes take place: micro-, meso- and macro-level. This is based on Geels and Kemp (2000), who use the division into niches, regimes and socio-technical landscapes to describe technological changes in socio-technical systems (Figure 3).

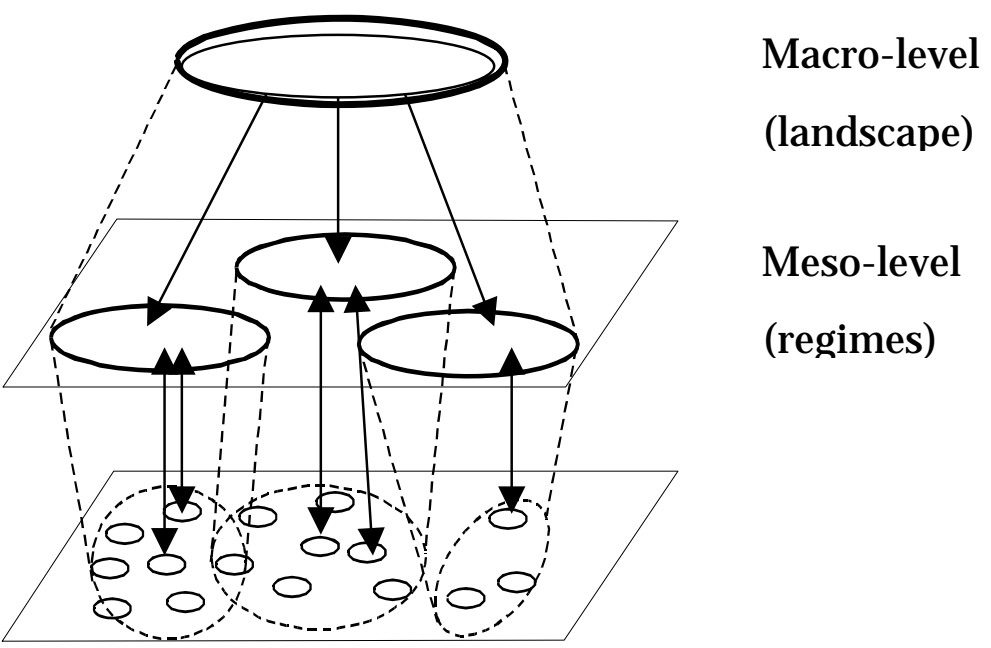

Figure 3. Multi-level concept is based on (Geels and Kemp, 2000). Developments at the macro-level correspond to slow broad societal trends. Dynamics at the meso-level are determined by the regime. The regime is the dominant pattern of actors, artifacts and structures in the social system. At the microlevel, individual persons, organizations, or innovations are distinguished. 
At the macro-level the societal landscape is determined by changes in the macro economy, politics, population dynamics, natural environment, culture and worldviews. This level responds to relatively slow trends and large-scale developments that play an important role in speeding up or slowing down a transition, but where its geology is for the most part unyielding. At the meso-level the regimes operate. Regimes are patterns of artefacts, institutions, rules and norms assembled and maintained to perform economic and social activities (Berkhout et al. 2003). At this level the dynamics are determined by their dominant practices, rules and shared assumptions, social norms, interests, rules and belief systems that underlie strategies of companies, organizations and institutions and policies of political institutions which are often geared towards preserving the status quo and thus towards optimisation and protecting investments rather than system innovations. At the micro-level (niche-level) individual actors, alternative technologies and local practices operate. At this level, variations to and deviations from the status quo occur as a result from new ideas and new initiatives and innovations, such as new techniques, alternative technologies and social practices (Kemp, Schot \& Hoogma, 1998).

Interlinking the two transition concepts of multi-level and multi-stage, yields the following pattern. In the pre-development phase of a transition the regime often acts as an inhibiting factor. Typically it will seek to maintain social norms and belief systems and to improve existing technologies. The take-off phase is reached when a modulation of developments takes place at the micro- and macro-level. This means that certain innovations at the micro-level, e.g. in terms of behaviour, policy or technology are reinforced by changes at the macro-level, e.g. changes in worldviews or macro policies. It can go either way: breakouts at the micro-level find fertile soil at the macro-level, or changes at the macro-level can be accompanied by suitable initiatives at the micro-level. An important characteristic in the transfer from the predevelopment-phase to the take-off is that different ideas or perspectives from different fields cross-fertilize and converge into one, more or less consistent paradigm. Often there is a period of polarization between the existing and emergent paradigm. Parts of the regime will become susceptible and try to find ways to integrate the new opportunities. This marks the take-off phase in which the dynamics within the dominant regime increasingly modulate with innovative experiments at the micro level. This is a highly uncertain period in which results are needed in order to push and pull the regime over the 'edge'. If these results are not produced there is danger of a drawback and the transition could suffer from a lock-in. In the acceleration phase, the regime has an enabling role, through the application of large amounts of capital, technology and knowledge. The regime changes as a result of selfexamination, in response to bottom-up' pressures from the micro-level and to 'topdown' pressures from the macro-level. Through the reinforcement of developments at the three different levels, dominant practices change rapidly and irreversibly. In the stabilization phase the acceleration slows down, due to a new regime that has been built up, again resisting new developments. The stabilisation phase represents 
another (relative) equilibrium, which could accommodate the seeds of change for another transition.

\section{TRANSITION MANAGEMENT}

The third concept of transition theory focuses on governing transitions, denoted as transition management. Transition management is a process oriented management philosophy that is rooted in fields as multi-level governance and adaptive management (Rotmans et al., 2000). Transition management is based on coordinating multi-actor processes at different levels, aiming at long-term sustainability through the creation of a joint problem perception and long-term vision, innovation networks and experimental playgrounds. Transition management is by definition anticipative and adaptive, as the degree of complexity of transitions is to high to be managed in terms of command and control. In other words, while transitions defy traditional planning, they can be influenced and adjusted in terms of the direction and pace of transitions. The basic underlying rationale for the management of transitions is that many past transitions that happened by chance did not result in a more sustainable society. On the contrary, often the detrimental environmental impact of transitions outweighed the positive impact. Thus initiating a transition from a preconceived goal of sustainability, which is inherently subjective, should arise from a multi-actor process, involving a balanced diversity of stakeholders.

Transition management encompasses four coherent developing lines which evolve in a cyclical and iterative way: (i) the establishment and development of a transition arena (an innovation network), which consists of a diversity of actors; (ii) the generation of long-term integrated visions, transition pathways and agendas; (iii) a steering process based on knowledge development and learning effects and (iv) monitoring and evaluating the transition process. This joint search- and learning process takes place in a transition arena, which operates at a distance from the current policy arena (See Figure 4.). The learning process has three components: learning-by-doing (developing theoretical knowledge and testing through practical experience), doing-by-learning (developing empirical knowledge and testing that against the theory) and learning-to-learn (developing learning strategies, applying and evaluating them). 


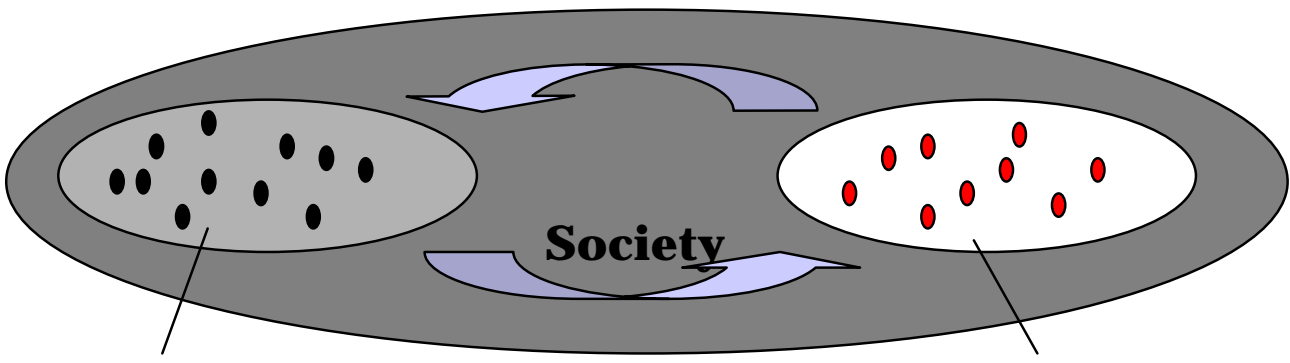

\section{Current policy arena}

- Short-term

- Peloton

- Incremental improvements
Transition arena

- Long-term

- Frontrunners

- System innovation

Figure 4. During the transition management process there are converging and diverging movements between the policy arena and the transition arena (Dirven, Rotmans and Verkaik, 2002). Initially there is divergence and the transition arena operates outside traditional institutional settings in order to develop innovative transition visions, agendas and experiments. Convergence takes place when the visions, agendas and experiments are matured enough to be adopted by the policy arena.

In the participatory setting of a transition arena, a selective number of representatives from various societal groups and domains (governments, business, knowledge institutes, NGO's and intermediaries) co-operate in creative sessions formulating a common problem perception and exploring desired futures. Then, several transition pathways that lead to these future visions are developed and explored through the use of scenarios, risk- and uncertainty-assessments and trendanalyses. Actively communicating this shared vision and transition pathways into other networks, should stimulate people to join the innovation network to build joint strategic agenda's. This so-called innovation network is a small but open network and consists of frontrunners, visionary people who are willing to put a considerable effort in conducting joint transition experiments. If each frontrunner would be able to set up an own transition arena the visionary ideas can evolve rapidly and spread unchecked.

In table 1 . the differences between current policy and transition management, denoted as transition 'policy', are presented. Current policy aims at consensus and short-term, incremental solutions, whereas transition policy starts from dissensus and long-term, radical solutions. 
- Short time horizon (5-10 years)

- Facet approach

- limited number of actors

- one scale-level

- one domain

- Aimed at incremental change

- Regular steering mechanisms

- Political arena

- Linear knowledge development and - Learning-by-doing and doing-by- learning
- $\quad$ Long time horizon (25-50 years)

- Integrated approach

- multi-actor

- multi-level

- multi-domain

- Aimed at innovation for sustainable development

- New steering mechanisms

- Transition-arena dissemination

Table 1. Key differences between current policy and transition policy (in terms of time horizon, approach, aim, steering mechanisms, arena, knowledge development). In this table, the differences are dichotomized for sake of clarity. A more appropriate conceptualization would be a set of continuous spectra.

In general, historical and current transition patterns can be analysed by using the three transition concepts, in terms of recognizing causal patterns, temporal dynamics, success and fail factors and governance patterns. The transition concepts provide a framework for unravelling complex transition patterns in a structured manner. However, due to a serious lack of reliable quantitative and qualitative data at this level of analysis, it is not yet possible to empirically test the transition concepts. Hence, one of the ambitions of future transition research is to build up a database of historical and current transitions.

\section{HISTORICAL ANALYSIS}

\subsection{The Predevelopment phase}

The historical trajectory studied spans a time period of about 30 years, starting with the construction of the Delta Works ('Deltawerken'), which seems in retrospect an important starting point. The construction of this prestigious water defence project in the Dutch province of Zeeland was a huge undertaking and unique in many aspects, driven by a culmination of the technocratic and scientific regime. However, the impressive dams had also profound consequences for ecosystems nearby. Aquatic ecosystems suddenly changed from saltwater systems to fresh water systems, which had dramatic consequences for its biodiversity (Interview Saeijs, van der Kleij, 2002) (Bosch \& Van der Ham, 1998). In order to prevent further ecological damage an environmental department was founded within the Delta Dienst, the institute that was responsible for the construction of the Delta Works. The Delta Dienst was part of Rijkswaterstaat, the main Dutch Governmental water institution. Rijkswaterstaat itself was a technologically oriented governmental body associated with the construction of huge physical infrastructures. It therefore suffered a bad reputation and had to face numerous protests against the environmental and landscape degrading constructions. At that time there was growing awareness of environmental 


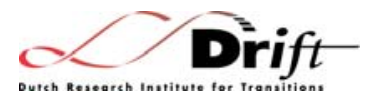

problems, both at the local and global level; the vulnerability of the environment due to human interventions was becoming clearer. At the global (macro) level, there was a deep ecological concern about the imbalance on a global scale between the explosive population grouth and ongoing economic development on the one hand, and the exploitation of natural resources and the environmental pollution on the other. The Club of Rome with their alarming report 'Limits to Growth' (Meadows et al., 1972) was a catalyst in this growing concern in the early seventies. At the local (micro) level the awareness arose that ecological and economic functions could directly harm each other, resulting in industrial pollution of water, soil and air (Interview Van der Kleij, 2002). The planning process for the construction of the Eastern Scheldt storm surge barrier, one of the most prestigious dams, started in the 1960's. When the protest against the Eastern Scheldt storm surge barrier became that loud that it transformed the local protest into a national debate, the construction plan changed in 1974 to a storm surge barrier with moveable panels to prevent ecological harm.

At the micro-level the research activities of the environmental department of the Delta Dienst led to a number of restoration projects, indicating the first signs towards a more ecological approach of the water regime. Between 1978 and 1982, the environmental department of the Delta Dienst was headed by H. L. F. Saeijs. One of his most important contributions was bringing biologists into the traditionally technologically oriented water management institutions (Interview Overmars, 2002). He can be considered as one of the promoters of the idea of a more ecologically oriented water management (Interview Verwolf; Overmars, 2002). After he became chief-engineer (director) of Rijkswaterstaat, department Zeeland, he confronted current water policy with a new approach focusing on the relation between the water system and the ecosystem. In 1985 major elements of this vision appeared in an official policy memorandum called 'Dealing with Water' (RIZA, 1985). This could be considered as a breakthrough with regard to a more integrated approach of water management. The report reached a wide audience, partly due to the ecological calamities evoked by the Delta Works. The systems approach advocated in this document represented a new way of thinking that proposed another perception of water as an integral part of an ecosystem in relation to its community (Saeijs, 1991) (Interview Saeijs, 2002).

Two important reasons why the ecological perspective resonated at the meso-level were firstly the growing number of biologists and secondly the re-organization of Rijkswaterstaat that took place. During the construction of the Eastern Scheldt storm surge barrier the Environment Department of the Delta Dienst grew quickly to over one hundred biologists and confronted the regime with the consequences of their practice (Bosch \& Van der Ham, 1998). When the Delta Dienst was officially removed in the re-organization process of Rijkswaterstaat in order to integrate water quantity and water quality policies, many former Delta Dienst biologists were placed in strategic positions (Interview van der Kleij, 2002). Although their language was quite different from the water engineers, they have cross-fertilized each other over time (Interview Saeijs, 2002; van der Kleij, 2002; Overmars, 2002). In this sense, Rijkswaterstaat became 'infected' with the new ideas. 


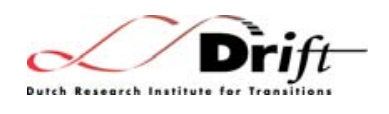

Although it is not possible to pinpoint the precise date at which the technocratic regime began to shift, we argue that the water transition started during the period in which the original construction plan of the Eastern Scheldt storm surge barrier was drastically changed. In the early 1970's the broad protest against the Eastern Scheldt barrier led to a drastic change of the construction plan, i.e. to a storm barrier with moveable panels to prevent irreversible ecological damage. Using the multi-level perspective, we see increasing modulation between the environmental awareness at the macro-level and the micro level, e.g. the Delta Dienst niche. The ecological problems resulting from the Delta Works and the re-organization of Rijskwaterstaat stimulated this modulation. However, the focus on a more ecologically oriented water management was still a niche compared to the dominant perspective.

However, in the following years, a number of other niches that presented alternative perspectives led to an increasing modulation between the three scale levels. One of them is 'Plan Ooievaar'. At a national contest called 'Netherlands - Riverland", the winning 'Plan Ooievaar' contested water management practices in the main rivers (De Bruin et al., 1987). Although the authors worked for the Dutch ministry of Agriculture, Nature and Fishery (LNV) and Rijkswaterstaat, they contributed on personal account. 'Plan Ooievaar' departed from a decoupling of agriculture and nature development, claiming that agriculture was damaging ecosystems (Interview Overmars, 2002) instead of considering agriculture as nature preservation. Thus 'Plan Ooievaar' broke with the current paradigm and alternatively put forward a coherent vision on the management of rivers, nature development and landscape architecture by separating conflicting water functions such as nature development and agriculture and interweaving water functions that would reinforce each other (Interview Overmars, 2002). In short, it comes down to substituting agricultural land for nature development areas in the river forelands. Hence, the plan broke from the traditional influence of agricultural demand in water management.

At the micro-level, a number of experiments based on the Ooievaar principles started in different regions, e.g. the Duursche Waarden, in Rhenen and the Gelderse Poort (Bosch \& Van der Ham, 1998). At the regime level the minister embraced the plan due the debate about the upcoming dike enhancements. W. Overmars, one of the authors of 'Plan Ooievaar', commented:

'It seemed like Plan Ooievaar got somehow sucked into these societal trends. If society had not wanted this, than 'Ooievaar' had been an utopia and the idea had been dismissed. Apparently, there was a kind of vacuum and when new ideas emerged they all got sucked in. And now it breaks through, directly to the minister, who promptly tells the media we are not constructing any dikes anymore. [...]"

Whereas 'Plan Ooievaar' focused on innovative water management for the main Dutch rivers, Dealing with Water' developed a vision on the water system as a whole. Both ideas reinforced each other by emphasizing the importance of natural processes in relation to different sorts of functions and complemented each other because of their different scope. The Third National Memorandum on Water Management (Rijkswaterstaat, 1989) elaborated on these principles and thereby postulating it as official national policy. Although this was an important strategic event, the implementation of this new paradigm was difficult, because of two reasons. First, the 


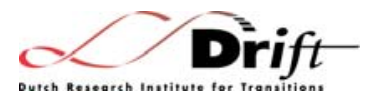

regime was mainly focused on agriculture as the organization of the water boards was traditionally organized for this purpose and second, the new policy concept had no direct link with the regimes other main duty of protecting the safety of the people. Hence, there was little sense of urgency about the implementation of the policy concept.

This link, however, was provided by a plan from the Dutch World Wildlife Fund (WWF) in 1992. The Dutch World Wildlife Fund was founded in 1990 and in order to position itself they published the plan Living Rivers' (WNF, Levende Rivieren', 1992) (Interview De J ong). In fact, it was an elaboration of 'Plan Ooievaar', but with a focus on the aquatic ecosystem itself. It proposed the idea of introducing side channels in the river forelands (flood plains) to reinstall broken food chains. Equally important, 'Living Rivers' presented an alternative for the planned dike enhancements by introducing side channels and excavation of the clay layers in the river forelands (Interview De J ong, 2002). Rijkswaterstaat embraced the plans of WWF that had broad support and sympathy among many civilians (Interview Verwolf, 2002).

In summary we can conclude that at the end of the eighties and the beginning of the nineties there was a series of developments and events that reinforced each other towards a new strategic vision on water management for the regional water systems and the main rivers. In a period of approximately 10 years important building blocks that were developed in niches were added to the concept of integral water management such as ecological preservation, nature development, food chain management and alternatives for dike enhancements. Thus overall, at the end of the eighties, the ecological calamities, the influence of the biologists and the innovative plans all began to change the perception of water management practice. From a transition perspective the WWF-plan is especially important in setting the conditions for modulation between the niches and the regime e.g. linking the niches to the regime by explicitly referring to a new strategy for water protection and bringing the transition to a new level.

\subsection{The take off}

At the macro-level Dutch policy in general promoted the decentralization of central government and stimulated liberalisation and privatisation. The decentralisation trend also affected Dutch water management. The proportion of work done by other parties than Rijkswaterstaat increased, the number of staff decreased and regional directories became less dependent on central government. On the one hand there was a shift of power that had consequences for the position of Rijkswaterstaat in the hierarchy and in its top-down policy. On the other hand the focus on ecological consequences required other competences and new professions in the regime of water engineering. The slow breakdown of the old regime paved the way for water management to become a more multi-disciplinary and less hierarchical managed regime.

Although at the meso-level the perspective was slowly changing towards the consideration of ecological values and interests, it had no significant influence upon the daily work of most people involved. Depending on the type of institution, the 


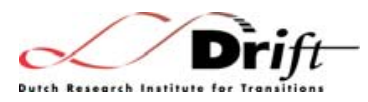

needs, the space to manoeuvre and the political choices, the regime slowly shifted into the same direction, but jerkily and heterogeneously. The Third National Memorandum on water management had significant impact in this process as it proposed a merger in the early nineties of the traditionally separated regional quantity water boards and quality water boards.

At the micro-level, the relationship between spatial planning and water management was already of interest in niches during the late eighties (Interview Saeijs, 2002). The report "Dealing with the Surrounding Area" ('Omgaan met de Omgeving') (Rijkswaterstaat, 1992) had already explored the integration of both policy domains, but not until the floods of 1993 and 1995 was there enough of a sense of urgency within the water regime to integrate policies. The floods made instantly clear that the current water management strategies could not fully control the water. Furthermore, what also became apparent was the increased danger and higher risk that would become of dike enhancements, were they to break. After Rijkswaterstaat recalculated the WWF-plan 'Living Rivers' with regard to the enlargement of the total river area as a result of side channels and excavation of clay layers in the floodplains, this actually became an alternative strategy for guaranteeing safety, other than dike enhancements.

In the short term the floods created a opposite response as the demand for further dike enhancements raised, but on the long term they have acted as catalysts by modulating the developments at the micro- and meso-level. From a transition perspective this seems to indicate a next stage in terms of modulation. At the mesolevel, the regime could no longer defy that the engineering approach as long-term strategy was not viable any longer. Thus, as a result of the floods, the regime had to abandon its dominant strategy and became susceptible for the alternatives that still remained at the micro-level, shifting the transition to the take-off stage.

After the floods, although the regime temporarily reverted to its traditional strategy of raising dikes in the 'Delta Plan Rivers', explicit integration of water and spatial planning was put forward in the Room for Rivers' report (Rijkswaterstaat, 'Ruimte voor Rivieren', 1995) that served as a discussion report in the preparation of the Fourth National Memorandum on Water Management. In 1998, the Fourth National Memorandum on Water Management focused on integral and participatory water management combined with a river basin approach. There was a strong reference to the upcoming Fifth National Memorandum on Spatial Planning (VROM, 2001) in which the spatial consequences of water management had to be further developed. Noticeably, the Fourth Memorandum on water management was created in an open planning process in which 3000 people participated, reflecting a noticeable change of water management compared to twenty years ago: from a hierarchical, closed engineering organization to a more open and participatory network institution.

In the midst of these changes, economic damage as a result of extreme precipitation in 1998, triggered the Council of Ministers to ask questions about the competence of contemporary regional water management. In response, Rijkswaterstaat, the provinces and regional water management boards launched the report Tackling Flooding' (Rijkswaterstaat 'Aanpak water overlast', 1998) and proposed to install a committee to investigate future water management. The resulting Committee- 


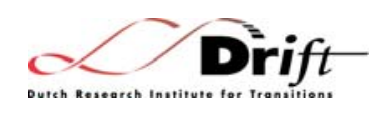

Tielrooy explicitly emphasized in its advice "Dealing differently with water, water management for the 21st century" (CW21 'Anders Omgaan met Water', 2000) the possible adverse effects of anthropogenic climate change within the next century. CW21 concluded that 'current water management was not sufficiently prepared to meet these future challenges'. It proposed a participatory and anticipative river-basin approach, a 'retaining-storing-draining' strategy and no negative trade-offs to other river basins. Above all, it promoted the 'room for water'-policy by the introduction of a so-called 'water test' in spatial planning processes. Dutch cabinet agreed and proclaimed it to official policy. The year after, the Fifth Memorandum on Spatial Planning postulated water as a 'guiding principle' in spatial planning. This was reinforced by the European Water Framework Directive (2000/60/ EC; WFD), which requires the active involvement of all affected parties in the river basin management plan (Pahl-Wostl, 2002). Although, it is quite a challenge knowing how to deal best with participation in international river basins (Mostert 2002), the WFD should be considered as an important modulating factor in terms of the pressure it exerts upon the Dutch water management regime with similar principles.

The transition is currently in a stage in which the integral, participatory water management paradigm is being implemented. Important steps in this process are the intention statements of the regional water management boards to the Tielrooy threestep strategy of 'retaining-storing-draining' (CW21, 2000); at the national level the 'Room for Water' policy has led to the designation of a number of 'calamity areas' that will be flooded in case of high discharge levels; at the regional level, long-term water basin visions are obligatory. However, there is a vivid debate on the practical aspects of implementation, involving the financial, legal and democratic aspects. An important instrument in this procedure is the so-called 'Water Test', which should enable water management to participate in an early stage in the spatial planning process. A major barrier still is the traditional way in which the water regime is organized. Many consider the organizational structure of the regional water boards as old-fashioned, claiming the water boards should be integrated with regional government (province), as spatial planning is a political and governmental mandate. This discussion has been fuelled by this summer's (2003) break of small local dikes (Wilnis and Rotte) as a result of the droughts. However despite the warnings issued by the knowledge center GeoDelft as to the vulnerability of these peaty dikes in periods of drought, the regional water board ignored them. In the Netherlands there are thousands of kilometres of this type of dikes of which we now know the regional water boards are not able to control. Questions are now raised as to whether we should expect water managers to foresee these kinds of dike problems. On top of this, anthropogenic climate change is expected to worsen the current situation, which creates a sense of urgency that might accelerate the water transition considerably.

With hindsight the emergence of an integral, participatory water perspective seems a logical and rather smooth development, but the actual historical path has been a whimsical and intermittent process. The transition process was the result of highly complex dynamic processes in the past three decades. Summarizing the multi-leveldevelopments, we can distinguish four types of developments: (i) built-up practical knowledge and advancing knowledge of practitioners who work on a daily basis on 
the water-related problems and in the predevelopment phase indicated at the microlevel that the overall situation was problematic, pointing to many unsustainable symptoms of the existing water system, and trying to come up with alternative solutions and setting up new organisations; (ii) developments at the macro-level such as anthropogenic climate change and sea level rise that were related to a higher frequency of flood occurrences, accompanied by a deep ecological concern as a result of the growing environmental awareness that reinforced the initiatives at the microlevel; (iii) slowly changing perceptions, procedures and organization of the water regime at the meso-level as a result of the pressure from the developments at the micro and macro-level pushing the transition slowly to the take off phase; and (iv) calamities, like the ecosystem damage in de Delta Works that triggered the transition and the floods in 1993 and 1995 that acted as catalysts in terms of modulation between the developments at the different scale levels resulting in a shift to the take off phase (See Table 2). 


\begin{tabular}{|c|c|c|c|c|c|c|}
\hline rechystem stat state $1975^{\text {ans }}$ & fíons Events & System state 1985 & - Events & System state 1995 & - $\quad$ Events & System state ' 04 \\
\hline \multirow[t]{2}{*}{ Supranational } & $\begin{array}{ll}- & \text { Growing } \\
\text { environmental } \\
\text { awareness } \\
\text { - } & \text { Economic growth } \\
\text { - } & \text { Limits to Growth }\end{array}$ & & - $\quad$ Rio Summit ('92) & & $\begin{array}{ll}- & \text { J ohannesburg } \\
\text { - } & \text { summit ('02) } \\
\text { - } & \text { Climate Change } \\
\text { - } & \text { Sea level rise } \\
\text { EU Water Framework } & \text { Directive } \\
\end{array}$ & \\
\hline & $\begin{array}{llr}- & \text { Delta } & \text { Works } \\
\text { Calamities } & \text { (ecological } \\
\text { impact) }\end{array}$ & & $\begin{array}{ll}\text { - } & \text { 1st } \quad \text { National } \\
& \text { Environmental Policy } \\
& \text { Plan } \\
- & \text { 1st Nature Policy Plan } \\
- & \text { Floods ('93, '95) }\end{array}$ & & $\begin{array}{ll}\text { - } & \text { National } \\
\text { Environmental Policy } \\
\text { Plan 2, 3, 4 (NMP2-4) } \\
\text { - Environmental } \\
\text { Management Act }\end{array}$ & \\
\hline $\begin{array}{ll}\text { - } & \text { Technocratic } \\
\text { water } \\
\text { management }\end{array}$ & \multirow{3}{*}{$\begin{array}{ll}- & \text { Delta Works } \\
- & 2^{\text {nd }} \text { National Policy } \\
\text { Memorandum Water } \\
\text { Management } \\
\text { Protests against water } \\
\text { management } \\
\text { approach }\end{array}$} & $\begin{array}{ll}\text { - } & \text { Water System } \\
\text { management }\end{array}$ & \multirow{3}{*}{$\begin{array}{ll}\text { - } & \text { 3d National Policy } \\
\text { Memorandum Water } \\
\text { Management ('89) } \\
\text { - } & \text { Re-organization } \\
\text { Rijkswaterstaat } \\
\text { - } \\
\text { Re-organization } \\
\text { - Regional water boards } \\
\text { Decentralization }\end{array}$} & $\begin{array}{ll}\text { Integral water } \\
\text { management }\end{array}$ & \multirow{3}{*}{ 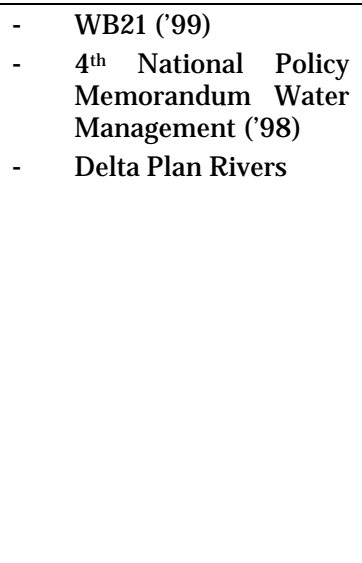 } & $\begin{array}{ll}\text { - } & \text { Adaptive water } \\
\text { management }\end{array}$ \\
\hline $\begin{array}{ll}\text { - } & \text { Engineering } \\
\text { approach } \\
\text { - } \\
\text { Hierarchical } \\
\text { organization (top- } \\
\text { down) }\end{array}$ & & $\begin{array}{ll}- & \begin{array}{l}\text { Engineering } \\
\text { approach }\end{array} \\
\text { - } & \begin{array}{l}\text { Hierarchical } \\
\text { organization (top- } \\
\text { down) }\end{array}\end{array}$ & & $\begin{array}{ll}\text { - } & \text { Room for Water } \\
\text { - } & \text { Democratic } \\
\text { organization } \\
\text { (Stakeholder } \\
\text { participation) }\end{array}$ & & $\begin{array}{ll}\text { - } & \text { Adaptation and } \\
\text { retention } \\
\text { - } & \text { Participatory Policy } \\
\text { process }\end{array}$ \\
\hline \multirow[t]{2}{*}{\begin{tabular}{ll}
\multicolumn{2}{l}{ Priorities: } \\
$-\quad$ & Safety \\
- & Agriculture
\end{tabular}} & & \begin{tabular}{ll}
\multicolumn{2}{l}{ Priorities: } \\
$-\quad$ Safety \\
$-\quad$ Agriculture \\
$-\quad$ Ecology
\end{tabular} & & \begin{tabular}{ll}
\multicolumn{2}{l}{ Priorities: } \\
- & Safety \\
- & Nature \\
& development \\
- & Agriculture \\
- & Spatial Planning \\
\end{tabular} & & \begin{tabular}{ll}
\multicolumn{2}{l}{ Priorities: } \\
- & Safety \\
- & Spatial Planning \\
- & Nature \\
& development \\
- & Agriculture \\
\end{tabular} \\
\hline & $\begin{array}{ll}\text { - } & \text { Environment dept. in } \\
\text { Delta Dienst } \\
\text { - } \\
\text { Dealing with water } \\
\text { ('85) } \\
\text { - } & \text { Restoration projects } \\
\end{array}$ & & $\begin{array}{ll}- & \text { Plan Ooievaar ('87) } \\
\text { - } & \text { Living Rivers ('92) } \\
\text { - } & \text { Dealing with the } \\
\text { surrounding Area } \\
\text { ('92) }\end{array}$ & & $\begin{array}{lll}- & \text { Room for Rivers ('95) } \\
\text { - } & \text { Tackling } \quad \text { Flooding } \\
& \text { ('98) }\end{array}$ & \\
\hline
\end{tabular}

Table 2. Scheme of developments at three levels of scale (macro, meso, micro) that have influenced the system state of water management in the Netherlands over a time period (1975 - 2004). System states are described in terms of management concept, approach and priorities $(1975,1985,1995,2004)$. 


\section{WATER TRANSITION MANAGEMENT}

Although the water transition is in the take-off phase, there is no guarantee that the transition will be completed successfully, which is underlined by the serious difficulties of implementing new practices and instruments. At the strategic level the concept of the new water management style is broadly shared, but at the operational level of implementation there are numerous practical questions. As long as there are severe incompatibilities between the strategic level and the operational level, the point of irreversibility will not yet be reached, meaning that the transition still can get stuck in a lock-in or lock-out. Transition management therefore aims at modulating these three different levels of governance.

Communication between the three levels of scale has to be organized into a joint learning process. A project in the Dutch villages Berkel \& Rodenrijs, Nootdorp and Lith (Valk and Wolsink, 2001) provides an example of the failure when the strategic level does not 'flow' with the operational level. The principle idea of the project was to integrate new building activities into a sustainable water system. In practice this meant a number of things: the creation of enough space for water; making the water system part of the destination plans and participation of the communities; maintaining the hydrological balance by retaining 'area-specific' and high quality water by letting water flow from clean to dirty; and creating a desirable environment for plants, animals and people. In practice, however, the importance of water was limited as opposed to the interests from stakeholders. Water was hardly a decisive factor in determining the location of the neighbourhood. Hence, the 'distance' between the strategic level and the operational level resulted in failure of the project.

In order to shift the traditional water management style, the modulation of different levels of scale has to be increased by aligning the different levels of governance. Table 3. contains the principles of the new water management style. The old water management style can be characterized by a control-paradigm with a sectoral and technological focus, whereas the new management style is based on an anticipation and reflection-paradigm with an integral and spatial focus. Underlying assumption of the new paradigm is that there are fundamental uncertainties about future physical and societal processes that cannot be easily reduced. These uncertainties can be approached and interpreted from different perspectives. A broad range of different stakes and perspectives therefore needs to be taken into account in the water management process. This requires a participatory and interactive approach that focuses on the long-term. Thus, the key elements of the management style are uncertainty, anticipation and participation (NRLO, 2000). 


\begin{tabular}{|c|c|c|}
\hline & $\begin{array}{c}\text { Water management style } \\
2^{\text {th }} \text { century }\end{array}$ & $\begin{array}{c}\text { Wwater management style } \\
22^{\text {st }} \text { century }\end{array}$ \\
\hline- & Command and control & $\begin{array}{ll}- & \text { Prevention and anticipation }\end{array}$ \\
\hline- & Focus on solutions & - $\quad$ Focus on design \\
\hline- & Monistic & - $\quad$ Pluralistic \\
\hline- & Planning-approach & - $\quad$ Process-approach \\
\hline- & Technocratic & - Societal \\
\hline- & Reactive & - $\quad$ Anticipative and adaptive \\
\hline- & Sectoral water policy & - Integral spatial policy \\
\hline- & Pumping, dikes, drainage & - $\quad$ Retention, natural storage \\
\hline- & Rapid outflow of water & - Retaining location-specific water \\
\hline - & Hierarchical and closed & - $\quad$ Participatory and interactive \\
\hline
\end{tabular}

Table 3. Key aspects and differences between the water management style of the 21st century and the water management style that was dominant throughout the 20th century.

Also is this table, the differences are dichotomized for sake of clarity. A more appropriate conceptualization would be a set of continuous spectra.

From a transition management point of view the process of envisioning and performing experiments are a co-evolutionary process. Innovative niches should be given sustained room to experiment and learn in order to develop new water management concepts or instruments. Niches like Plan Ooievaar' and 'Living Rivers' are perfect examples of the added value of cross-fertilization between different domains. Such niches have introduced new ways of looking at water and water management by departing from the regular thinking pattern, like nature development, aquatic communities or spatial planning. At the same time they have provided integral water management with a set of tools and instruments that allow for practical implementation. In retrospect, we could argue that the environmental department of the Delta Dienst, 'Plan Ooievaar' and Living Rivers' and the Tielrooycommittee could be considered as different transition arenas in which transition visions were developed. However, these transition arenas originated accidentally and not as a result of a pre-conceived transition management strategy. The innovative visions at the micro-level remained, for quite a long period, at a 'distance' from the dominant regime at the meso-level. On the other hand, the long pre-development phase matured the initial ideas and concepts from the various niche arenas.

The above shows the possibility of coordinating transition processes when a variety of innovative experiments can be attuned and embedded in a broad process of learning. Transition management aims to coordinate and stimulate the interaction between innovative niches at the micro-level and the dominant, conservative regime at the meso-level by tying different activities at different scale levels. This involves the following steps as part of a cyclical and interactive process: a joint problem perception, multi-actor strategies, vision- and agenda-building, experimentation and monitoring and evaluation (See Figure 5). The different activities coincide with three 
levels of scale at which policy and negotiation processes take place (Loorbach \& Rotmans, 2006). The transition arena operates at a strategic level, which focuses on the macro developments and the development of macroscopic visions, new paradigms and pathways. A broader innovation network operates at a tactical level and spreads the new ideas, deliberating different agenda's and policies and trying to develop joint agenda's. The third level is the operational level where nicheexperiments and -projects are carried out. In practice these activities happen at all three levels simultaneously and iteratively. The challenge for transition management is to connect, coordinate and align these developments in such a way that they reinforce each other and induce structural changes in the long-term.

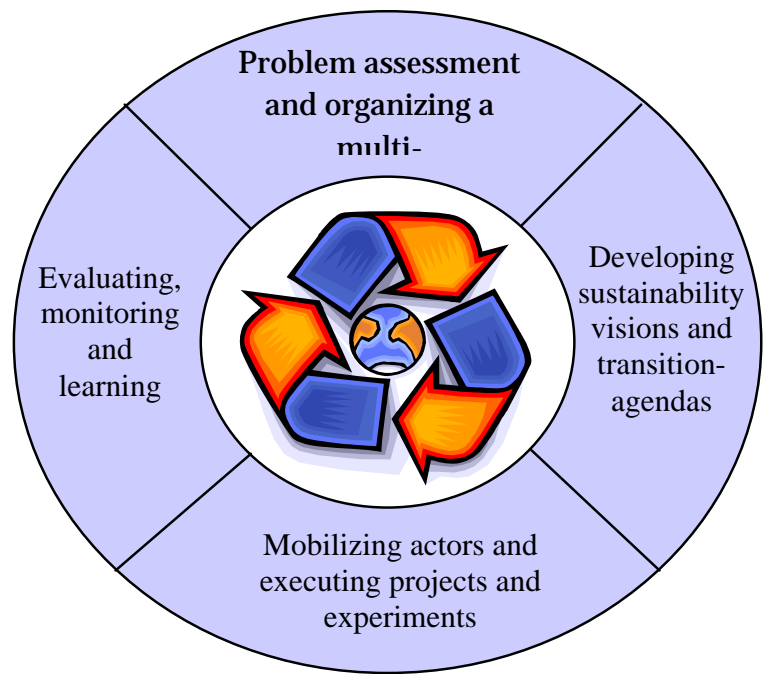

Figure 5. Transition management is a cyclical coordinated multi-actor process at strategic, tactical and operational levels and is organized around four co-evolving activity clusters (1) the establishment and development of a transition arena; (2) the creating of long-term integrated visions, transition pathways and agendas; (3) mobilizing actors and knowledge development through experimenting and (4) monitoring and evaluating the transition process (Loorbach \& Rotmans, 2006).

In terms of organisation and coordination, a water transition arena needs to be organized by an independent intermediary or facilitating organization based on an integrated systems analysis: assessing historical trends and developments, future trends and scenarios and actors and institutions involved. We have only made a preliminary attempt here. The water transition arena should consist of a small number of people, selected on specific competences like innovative capability, network ability, cross-domain and visionary thinking, creativity and relevant knowledge of the field. The selected participants should join on personal account rather than representing their home organization or institution, in order to avoid a rather narrow focus on the short-term stakes and vested interests of their occupational background. Together they develop a long-term sustainability vision that consists of a set of qualitative images in which they illustrate and visualize a future sustainable water system and what the framing conditions are (Dirven, Rotmans \& Verkaik, 2002). These images should contain physical and spatial elements as well as elements of the new water management style, such as risk management in terms of anticipative and adaptive water management strategies, 'openness' towards other policy domains, institutional organisation with regard to participation from stakeholders (see also table 3.). This change in the nature of the 


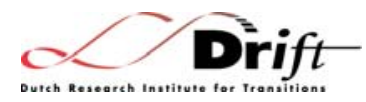

water management process means that another type of water managers is required (Rotmans, 2003). In modern water management knowledge from the 'social sciences' is evenly important as hydrological or engineering knowledge. Furthermore, communication skills are very important when managing multi-stakeholder policy processes. Going through this process of change in water management requires a learning process in which different transition experiments are learning opportunities. A broad variety of experiments is possible such as the creation of retention areas, using water as a guiding principle in the construction of neighbourhoods, new rules and regulations for integral, participatory water management, or experiments dealing with new ways of combining agriculture and nature-conservation using new participatory methods in the decision-support processes.

\section{CONCLUSION}

The water-related problems in the Netherlands are the result of the whole of human interventions in the water system over the last century. Large-scale societal trends, physical processes and human interventions have led to increasing pressure from the land on the water and increasing pressure from water onto the land. The water system, both the physical infrastructures as well as the water governance system, has become unsustainable in terms of reduced safety, costs and ecological damage, and in which the floods are mere symptoms of these deeper fundamental problems. In order to cope with future threads like anthropogenic climate change and changing societal demands, water management is in the middle of a fundamental change process that started in the 1970's towards a more adaptive and participatory form of water management.

We have investigated if the historical developments in Dutch Water management can be characterized as a transition. Based on longitudinal research through an integrated system analysis, document research and expert interviews, we have reconstructed the historical narrative by using the transition concepts of multi-level and multi-phase. This research indicates that the shift in Dutch Water management indeed can be characterized as a transition that is currently in a crucial stage, in the take-off and near the acceleration phase. An important demarcation point of the start of this transition was in the 1970's at the time the plan of the Eastern Scheldt storm surge barrier was adjusted. During the pre-development phase there was an ongoing process of integration between water management and nature development. This was fuelled by the growing ecological concern, empirical knowledge, learning experiences and cross-fertilization. The floods have acted as catalysts by modulating initiatives at the micro-level with the growing recognition among water managers that the water problems were the result of an unsustainable water system at the meso-level and the threat of anthropogenic climate change at the macro-level, shifting the transition to the take-off stage.

An interesting question from a management point of view is whether this transition has been managed. Although it has not been managed in the traditional meaning of the word, it was managed in terms of stimulating new initiatives from frontrunners at the micro-level, providing sustained room to develop these ideas, for example 
through the Netherlands - Riverland contest. The upscaling of these ideas took place when niche players reached strategic positions as a result of institutional reconfiguration, and were catalysed by the occurrence of major floods. Creating space for innovation, inside as well as outside the regime, has been crucial in breaking the dominant perspective and practice. In order to bring this transition process forward to a next stage, the space for innovation needs to be further expanded and directed towards the operational level. Furthermore, water managers should be trained to deal with such transition processes and a new water-innovation network should further facilitate and coordinate the transition.

\section{Literature}

- Berkhout, F., Smith, A., Stirling, A. (2003) Socio-technical regimes and transitions contexts. SPRU Electronic Working Paper Series.

- Bosch, A., Ham, W. van der. (1998) Twee eeuwen Rijkswaterstaat, 1798-1990. (Two centuries Rijkswaterstaat, 1798-1990). Zaltbommel: Europese Bibliotheek.

- Bruijn, D. de., Hamhuis, D., Nieuwenhuijze, L. van., Overmars, W., Sijmons, D., Vera, F. (1987) Ooievaar: De toekomst van het Rivierengebied. (Ooievaar: the future of the riverland). Gelderse Milieufederatie. Arnhem, The Netherlands.

- CW21 (2000) Anders Omgaan met Water. Waterbeleid voor de 21e eeuw. (Dealing Differently with Water, Water management for the $21^{\text {st }}$ century.). Committee Tielrooy, Ministry of Transport, Public Works and Water management / Union of Waterboards. The Hague, The Netherlands.

- Dirven, J., Rotmans, J. and Verkaik, A.P. (2002) Samenleving in transitie, een vernieuwend gezichtpunt. (Society in Transition: an Innovative Viewpoint). Essay, The Hague, The Netherlands.

- Geels, F. and Kemp, R. (2000) Transities vanuit sociotechnisch perspectief (Transitions from a sociotechnical perspective), Maastricht, The Netherlands.

- Ham, W. van der. (1999) Heersen en Beheersen, Rijkswaterstaat in de twintigste eeuw. (Rule and Control, Rijkswaterstaat in the 20th century). European Library, Zaltbommel, The Netherlands

- Kemp, R, Schot, J, Hoogma, R (1998) Regime shifts to sustainability through the process of niche formation. The approach of Strategic Niche Management, in: Technology analysis and Strategic Management, 10(2): 175-195

- Lintsen, H. (2002) Two Centuries of Central Water Management in the Netherlands. Technology and Culture, 2002, 43.549-568.

- Loorbach, D. and Rotmans, J. (2006) Managing transitions for Sustainable Development, in: Wieczorek, A.J., Olsthoorn X. (eds) Industrial Transformation - 
Disciplinary approaches towards transformation research. Kluwer, The Netherlands. Forthcoming.

- Martens, P., Rotmans, J . (2002) Transition in a globalising world. Swets \& Zeitlinger B.V. Lisse, The Netherlands.

- Meadows, D.H., Meadows, D.L., Randers, J . and Behrens, W.W. (1972) The limits to growth. Universe Books, New York, USA.

- Mostert, E. (2003) The Challenge of public participation. Water Policy Vol. 5 No. 2 179-197.

- NRLO, (2000) Over Stromen: Kennis en Innovatie opgaven voor een Waterrijk Nederland (About floods: knowledge and innovation for water), NRLO-rapport 2000/04, The Hague, The Netherlands.

- Pahl-Wostl, C. (2002) Participative and stakeholder-Based Policy Design, Evaluation and modeling Processes. Integrated Assessment. Vol. 3. NO. 1 pp. 3-14

- Rijkswaterstaat (1995) Ruimte voor Rivieren (Room for Rivers). Ministry of Transport, Public Works and water management. The Hague, The Netherlands.

- Rijkswaterstaat (1998) Aanpak wateroverlast (Tackling flooding). Ministry of Transport, Public Works and water management. The Hague, The Netherlands

- Rijkswaterstaat (1998) Vierde Nota Waterhuishouding (Fourth National Policy Memorandum on Water management). Ministry of Transport, Public Works and water management. The Hague, The Netherlands.

- Rijkswaterstaat (1995) Ruimte voor Rivieren (Room for Rivers). Ministry of Transport, Public Works and water management. The Haque. The Netherlands.

- Rijkswaterstaat, (1992) Omgaan met de Omgeving (Dealing with the surrounding area). Ministry of Transport, Public Works and water management. The Hague, The Netherlands.

- Rijkswaterstaat (1989) Derde nota Waterhuishouding (Third National Policy Memorandum on Water management). Ministry of Transport, Public Works and water management. The Haque, The Netherlands.

- Rijkswaterstaat (1982) Tweede nota Waterhuishouding (Second National Policy Memorandum on Water management). Ministry of Transport, Public Works and water management. The Haque, The Netherlands.

- Rijkswaterstaat (1964) Eerste nota Waterhuishouding (First National Policy Memorandum on Water management). Ministry of Transport, Public Works and water management. The Haque, The Netherlands. 
- Rittel, H., Webber, M. (1973) Dilemma's in General Theory of Planning. Policy Sciences. Vol 4. (2), 155-159.

- RIZA, (1985) Omgaan met water (Dealing with water). The Hague, The Netherlands.

- Rotmans, J. (1994) Transitions on the move. Global Dynamics and Sustainable Development. Rijksinstituut voor Volksgezondheid en Milieu (RIVM). Bilthoven, The Netherlands.

- Rotmans, J., Kemp, R. and van Asselt, M.B.A. (2000) Transitions \& Transition Management, the case of an emission-free energy supply. International Centre for Integrative Studies, Maastricht, The Netherlands.

- Rotmans. J. (2003) Transitiemanagement. Sleutel voor een duurzame Wereld. (Transition Management. The key for a sustainable society). Koninklijke Van Gorcum. Assen. The Netherlands.

- Saeijs, H.L.F. (1991) Integrated water management. A new concept: from treating of symptoms towards a controlled ecosystem management in the Dutch delta. Lands and Urban Planning 20, 245-255.

- Valk, D. and Wolsink, M. (2001) Water als Ordenende factor (Water as guiding principle), Rooilijn no. 6, 2001, p. 382-388.

- Verbong, G. (2000) The Dutch government and energy transitions: a historical perspective. Research document for the report Transitions \& Transition management, the case for an emission free energy supply (Rotmans e.a., 2000), TUE, Eindhoven. The Netherlands.

- VROM (2001) Vijfde nota over de Ruimtelijke Ordening (Fifth National Policy Memorandum on Spatial Planning), The Hague, The Netherlands.

- World Wildlife Fund (1992) Levende Rivieren (Living Rivers). Zeist. The Netherlands.

\section{Acknowledgements:}

We would like to thank the following persons for their cooperation in the interviews done:

Prof. dr. H. L. F. Saeijs; Ir. W. van der Kleij (TAW, Technical Advisory Committee for Embankment.); Ir. G. Verwolf, (Regional Waterboard 'de Veluwe'); Drs. W. Overmars, (Consultancy Bureau Willem Overmars) Dr. L. de J ong, (World Wildlife Fund); Drs. H. Kamphuis (Ministry of Housing, Spatial Planning and Environment); Drs. J. W. Bruggenkamp (RIZA) 